\title{
Biyosentez yöntemi ile üretilen GO: Se nanopartiküllerinin üretimi ve karakterizasyonu ve GO: Se nanopartikülleri kullanılarak geliştirilen Ag / GO: Se / p-Si cihazının akım-gerilim özellikleri
}

\author{
Tuba Çakıc1 ${ }^{*}$ \\ ${ }^{1}$ Atatürk Üniversitesi, İspir Hamza Polat Meslek Yüksekokulu, Elektrik ve Enerji Bölümü, Erzurum, Türkiye (ORCID: 0000-0003-3130-996X)
}

(İlk Geliş Tarihi 1 Kasım 2019 ve Kabul Tarihi 31 Aralık 2019)

(DOI: 10.31590/ejosat.665070)

ATIF/REFERENCE: Çakıcı, T. (2019). Biyosentez yöntemi ile üretilen GO: Se nanopartiküllerinin üretimi ve karakterizasyonu ve GO: Se nanopartikülleri kullanılarak geliştirilen Ag / GO: Se / p-Si cihazının akım-gerilim özellikleri. Avrupa Bilim ve Teknoloji Dergisi, (17), 1367-1374.

Öz

Son zamanlarda, nanopartiküllerin üretiminde kullanılan bilinen yöntemlerin yanı sıra yeşil sentez yönteminin kullanılması araştırmacılar tarafından büyük ilgi görmüştür. Bu çalışmada ilk kez literatürde, karanlık koşullar altında Luria-Bertani OG1 besiyerinde özel bir bakteri kullanarak yeni bir yeşil sentez yöntemi yaklaşımıyla selen katkılı grafen oksit nanoparçacıklarının (GO: Se-NPs) üretilmesi sağlandı. Bu işlemden sonra biyosentezlenmiş GO: Se-NPs solisyonu elde edildi. Bu çözelti p-Si altlık üzerine damlatıldı ve tavlama ile GO: Se ince filmi oluşturuldu. İnce film numunelerinin karakterizasyonu, ultraviyole görünür spektrofotometre (UV-VIS), $\mathrm{X}$-1şını difraksiyonu (XRD), alan emisyon taramalı elektron mikroskobu (FE-SEM) ile beraber olan enerji dağılımlı X-ışını spektroskopisi (EDS) teknikleri kullanılarak yapıldı. UV-VIS ölçümleri, GO: Se ince filminin bant aralık enerjisinin (1.70 eV) olduğu ortaya konmuş ve bu değer ilk kez bu çalışma ile literature girmiştir. XRD ölçümlerinde GO: Se / p-Si yapısının çok kristalli bir yapıya sahip olduğu görülmüştür. Diğer taraftan, FE-SEM görüntüsü ise nanometre ölçeğine sahip tabakalı ve kristal yapıların oldukça düzenli ve homojen bir şekilde dağıldıklarını göstermektedir. Öte yandan, akım- gerilimi (I-V) ölçümleri, Ag doğrultucu ve Al omik kontaklı GO: Se / p-Si hetero-yapısının bir diyot davranışı gösterdiğini kanıtlamıştır.

\section{Production and characterization of GO:Se nanoparticles produced by biosynthesis method and current-voltage characteristics of the Ag/GO: Se/p-Si device developed by using GO:Se nanoparticles}

\begin{abstract}
Recently, nanoparticle production through the use of green synthesis method as well as the known methods used in the production of nanoparticles has attracted a great deal of interest by researchers. In this recent research, it was first, achieved to produce graphene oxide: selenium nanoparticles (GO: Se-NPs) employing a new approach of green synthesis method using special bacteria OG1 in LuriaBertani medium under dark conditions in literature. Applying this method, biosynthesized GO: Se-NPs solution was obtained. GO: Se thin film was formed dropping this solution on the p-Si substrate, and then it was annealed. Optical, structural, morphological, chemical composision properties of GO: Se nanostructural thin film was determined by commonly preferred as UV-VIS, XRD, and FE-SEM with EDS techniques. UV-VIS measurements showed that the band gap energy, Eg, of the GO: Se thin film is $1.70 \mathrm{eV}$ and this value is firstly determined with this study in literature. XRD measurements revealed that GO: Se/p-Si structure has a particle nano size polycrystal structure. FE-SEM measurements have indicated that GO: Se thin film has a typically nano sheeted structure and distribution of the grains which are very homogeneous and uniform. Furthermore, Current-Voltage (I-V) measurements proved that GO: Se/p-Si heterostructure with rectifying contact of $\mathrm{Ag}$ and ohmic contact of $\mathrm{Al}$ exhibits a diode characteristic behavior
\end{abstract}

Keywords: GO: Se, Microbial Green Biosynthesis, Nanoparticles, Thin film.

\footnotetext{
* Sorumlu Yazar: Tuba Çakıcı, Atatürk Üniversitesi, İspir Hamza Poalt MYO, Elektrik ve Enerji Bölümü, Erzurum, Türkiye, ORCID: 0000-0003-

3130-996X, tuba.cakici@atauni.edu.tr
} 
Avrupa Bilim ve Teknoloji Dergisi

\section{Giriş}

For a few decades, nanotechnology, resulting from its nanosized nature, has attracted a great intence attention among the scientists since it promises innovations in many areas, such as, photovoltaic cells, light-emitting diodes (LEDs), optoelectronics, photocatalysis, single-electron transistors, and especially the production of different types of industrial materials [Oremland et al., 2004]. Scientists have studied densely for the production of nanoparticles and also tried to develop the new technologies for their productions. They have begun to use different methods for the fabrication of nanoparticles based on biological, physical, and chemical techniques. But, some of these techniques have advantages or disadvantages in producing nanoparticles. In the use of chemical technique among them has some disadvantages resulting from most of the chemicals which are not used being toxic and leading for the formation of the non-environmentally friendly by-products. On the other hand, biologic methods have many advantages compared to other techniques. These methods are easy and low-cost systems and they are also eco-friendly. Therefore, these methods known as "green nanotechnologies" are mostly required for the fabrication of the elemental metallic nanoparticles [Ozdal et al., 2016]. Today, it is known that many metals or metal-containing nanoparticles can be produced by biological organisms, such as various plants, algae, fungi, and bacteria. Among these organisms, like Pseudomonas, Escherichia, Vibrio, Pseudomonas, Bacillus bacteria have been studied intensely by scientists for synthesizing these nanoparticles.

For the last days, researchers have begun to study the graphene as a favor material due to its potential technological applications owing to its excellent optical, electrical, structural and mechanical properties [Bakir et al., 2017]. Many researchers have studied on the graphene oxide (GO) named from the oxide form of the graphene and they have investigated this material in detail since it has a tunable band gap, governable conductivity close to insulators, and high transmittance [Mekki et al., 2016; Kang et al., 2013]. Due to the properties of GO mentioned above, it has been seen that this material can be used as an interfacial thin film layer in the metalsemiconductor heterojunction structures. Kocyigit et al. have obtained GO: SiO2 nanoparticles by a chemical method and then using spin coating technique, they formed $\mathrm{GO}: \mathrm{SiO}_{2}$ interfacial thin-film layer between the p-Si semiconductor substrate and $\mathrm{Al}$ metal contact and obtained $\mathrm{Al} / \mathrm{GO}-\mathrm{SiO}_{2} / \mathrm{p}-\mathrm{Si}$ diode device structure [Kocyigit et al., 2018]. After completing the construction of the device, they have investigated its photovoltaic and photodiode properties. In another study carried by Kaya et al. [Kaya et al., 2016], they have constructed GO-doped $\mathrm{PrBaCoO}$ nanoceramic/n-Si capacitor device structure. They investigated the capacitive properties of the device using the data obtained from the impedance spectrometer measurements in a frequency range of $1 \mathrm{kHz}-1 \mathrm{MHz}$ at room temperature. Mekki et al. have done a similar study and obtained GO by the chemical method [Mekki et al., 2016]. But they, unlike Kaya et al., doped coumarin with different ratios into GO to change its photosensitivity and constructed a photosensor device to be used for optic communications placing this composite between the interface of p-Si crystal and Au metal contact. On the other hand, Jilani et al. have used GO for different goal doping coumarin with different ratios into GO to change the photosensitivity of coumarin dopped $\mathrm{GO} / \mathrm{p}-\mathrm{Si}$ diode that they constructed as a photosensor device to be used for optic communications [Jilani et al., 2013].

Schottky-type metal-insulator-semiconductor photovoltaic cell has been fabricated by Liu et al. and they employed GO as an insulator interlayer between the semiconductor and metal contact and also, they have proved that the developed photovoltaic cell by them has a rather high-power conversion efficiency [Liu et al., 2013]. Furthermore, there are several of the researchers investigating the production of GO and its effect on improving the electrical conductivity of the material when it is doped into it. Chen et al., in their study, have synthesized GO by altered Hummers method and then they obtained GO: coumarin nanoparticles mixing two solutions including GO and coumarin [Chen et al., 2010]. Then, they have constructed coumarin dopped GO/p-Si structure with different percentages of coumarin and investigated its I-V characteristics. Z.J. Li et al. have studied GO and they fabricated supercapacitor using GO nanoparticles [Li et al., 2012]. But, among these studies, it was not found binary GO: Se nanoparticles obtained by the biological method. Instead, many studies have been conducted on the acquisition of single metal nanoparticles through green synthesizing. Ponarulselvam et al. have achieved silver nanoparticles using the leaves of the extracts and revealed that it is active against the parasite malaria [Ponarulselvam et al., 2012]. Anuradha Prakash et al. have obtained nanoparticles (NPs) such as cadmium, silver, and lead synthesizing them on the surface wall of the bacteria called Bacillus megaterium and characterize them in detail [Prakash et al., 2018]. Mostafa M. Abo Elsouda et al., in this current work, have achieved to produce metallic tellurium nanoparticles (TeNPs) reducing potassium tellurite utilizing fungal Aspergillus welwitschias and proved their antimicrobial activities [Mostafa et al., 2018]. The previous research concentrated on metals or elemental nanoparticles synthesized by microorganisms. There appear no research binary nanoparticles synthesized by microorganisms or other green synthesis methods.

In this report, for the first time, GO: Se nanoparticles were obtained by a special bacterium and GO: Se nanoparticles were sintered on glass and p-Si substrates to obtain GO: Se thin films. GO: Se thin films were characterized by UV-VIS, XRD, FE-SEM, and EDX techniques. Ag metal evaporated on directly GO: Se/p-Si structure as a rectifier contact and Ag/GO: Se/p-Si diode structure was constructed. Current-Voltage measurements were carried out at room temperature to assign the numerical values of some electrical parameters of the fabricated device, such as ideality factor, $\mathrm{n}$, barrier height, $\phi \mathrm{b}$, and saturation current, $\mathrm{I}_{0}$. 


\section{Materials and Methods}

\subsection{Preparation of GO: Se Nanoparticles}

To achieve the synthesis of GO / Se nanoparticles in a solution by a selected special bacteria, the the way has been followed step by step as following;

To do this, it was used a specially selected bacteria P. aeruginosa strain OG1 [Ozdal et al., 2016a; Ozdal et al., 2017a]. Many bacteria can grow under extreme conditions such as high salt, pesticide, metal concentrations [Raddadi et al., 2015; Ozdal et al., 2017b; Ozdal et al., 2016b]. One of these bacteria is P. aeruginosa and it produces various types of enzymes, pigments, and biosurfactants, which enhance it to survive under very difficult conditions. P. aeruginosa can produce graphene [Gurunathan et al., 2013], Au [Husseiny et al., 2007], Ag [Kumar and Mamidyala, 2011] by direct electron transfer.

P. aeruginosa bacteria, first, as mentioned in our previous study, was cultured [Çakıcı, 2019; Çakıcı et al. 2019]. The cell suspension (100 $\mu$ l, OD600 1) was taken from inoculums and inoculated into the Luria Bertani Broth mediums $(20 \mathrm{~mL})$ and added $0.5 \mathrm{mM}$ graphene oxide and $0.5 \mathrm{mM} \mathrm{SeO}_{3}^{-2}$ into this medium. Hence, the biosynthesizing process of the nanoparticles was started at room temperature and dark conditions during 96 hours on rotating shaker (150 rpm). On the other hand, the same experimental processes were repeated for only $0.5 \mathrm{mM}$ SeO32- and $0.5 \mathrm{mM}$ graphene oxide after adding them to another culture solution. After this application, it was seen that the color of the reaction mixtures was changed during the biosynthesizing process from yellow to a reddish-brown color demonstrating the production of GO: Se nanoparticles. Fig. $1 \mathrm{a}, \mathrm{b}$, c show change in the color of selenium, GO, and GO: Se nanoparticles from light yellow to reddish pink, from dark yellow to black, and from green-yellow to reddishbrown in $96 \mathrm{~h}$, respectively.

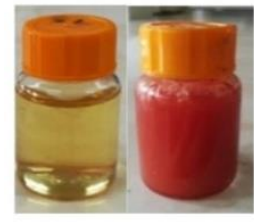

(a)

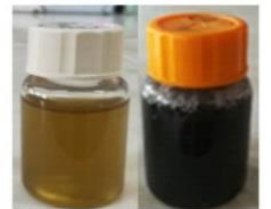

(b)

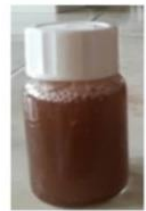

(c)

Figure 1: Change in the color of Se, GO, and GO: Se nanoparticles (a) from light yellow to reddish pink, (b) from dark yellow to black, and (c) from green-yellow to reddish-brown in $96 \mathrm{~h}$, respectively.

Then nanoparticles were cleaned and removed from the bacteria cellular impurities. [Oremland et al., 2004; Yoshida et al., 2016; Wadhwani et al., 2017]. This process is described in detail in our previous studies [Çakıcı, 2019; Çakıcı et al. 2019]. After this, cleaned Se (0), GO and GO: Se nanoparticles were suspended again in deionized water. The final solution was filtered and the material obtained after filtering was rinsed with deionized water again. After this process, only GO: Se nanoparticles remained in solution. A 50cc solution of GO: Se nanoparticles were directly dropped on the surface of the p-Si and glass substrates formed on as mentioned above, and then they were dried on a heater plate at $65^{\circ} \mathrm{C}$ for $75 \mathrm{~min}$. Hence, GO: Se thin films were synthesized both glass and p-Si substrates. The thin films formed on the glass substrates were separated for their characterization and the GO: Se thin films were separated for the fabrication of $\mathrm{Ag} / \mathrm{GO}: \mathrm{Se} / \mathrm{p}-\mathrm{Si} / \mathrm{Al}$ device.

\subsection{Characterization of GO:Se Thin film}

After the production of the GO:Se thin films, characterization of the thin films was performed. The optical characterization of the GO:Se thin film was examined by using UV-VIS Perkin-Elmer Lambda 2S UV-Visible spectrometer method from the glass substrate. Crystal structure properties and surface morphology were investigated from the p-Si substrate by using X-rays diffractometer XRD Bruker D2, K $\alpha, \lambda=1.54$ Ao and field emission scanning electron microscopy FE-SEM Sigma 300 Model Zeiss Gemini, respectively. Qualitative analysis of GO:Se thin films were determined by using electron diffusion X-ray, EDS equip with FE-SEM method.

\subsection{The Fabrication Process of Ag /GO: Se / p-Si / Al Diode}

In order to fabricate to $\mathrm{Ag} / \mathrm{GO}: \mathrm{Se} / \mathrm{p}$-Si / Al diode structure, p-type Si crystals were degreased with acetone and methanol in an ultrasonic cleaner for 10 min consecutively and they were etched in a sequence of $\mathrm{H}_{2} \mathrm{O}: \mathrm{H}_{2} \mathrm{O}_{2}: \mathrm{HNO}_{3}(6: 1: 1)$ at $60{ }^{\circ} \mathrm{C}, 20 \% \mathrm{HF}$ and a solution of $\mathrm{H}_{2} \mathrm{O}: \mathrm{H}_{2} \mathrm{O}_{2}: \mathrm{HCl}(6: 1: 1)$ at $60^{\circ} \mathrm{C}, 20 \% \mathrm{HF}$. Finally, the substrates were rinsed thoroughly in de-ionized water with a resistivity of $18 \mathrm{M} \Omega \mathrm{cm}$. After the chemically cleaning process, an electrode (Ohmic contact) was formed thermally evaporating $\mathrm{Al}$ onto the backside of the $\mathrm{p}$-Si substrate in a vacuum system with a pressure of $1 \times 10^{-5}$ Torr. Then, to improve the conductivity of the electrode, $\mathrm{p}$-Si/Al, each of these substrates was annealed in an oven at $550^{\circ} \mathrm{C}$ for 3 minutes in a nitrogen atmosphere. Other $\mathrm{Ag}$ metal electrode applying with shadow mask was evaporated on directly GO: Se thin film surface as rectifying contacts. Rectifying $\mathrm{Ag}$ metal contacts were formed cylindrical geometry of $1.00 \mathrm{~mm}$ diameter in vacuum pump (1.5 $10^{-5}$ Torr $)$. After this process, fabrication of the $\mathrm{Ag} / \mathrm{GO}: \mathrm{Se} / \mathrm{p}-\mathrm{Si} / \mathrm{Al}$ diode structure was completed.

$\mathrm{I}-\mathrm{V}$ characteristics of the $\mathrm{Ag} / \mathrm{GO}: \mathrm{Se} / \mathrm{p}-\mathrm{Si} / \mathrm{Al}$ diode structure was performed in our laboratory and electrical properties of the diode structure were determined to conduct the measurements at room temperature $\left(300^{\circ} \mathrm{C}\right)$ by using Keithley 2400 Source Meter System (current-voltage measurement system). 


\section{Results and Discussion}

\subsection{Optical properties}

The optical absorption spectrum from UV-VIS measurements of GO: Se thin film sample depending on the wavelength of the photon varying from 300-1000 $\mathrm{nm}$ is given in Fig. 2.

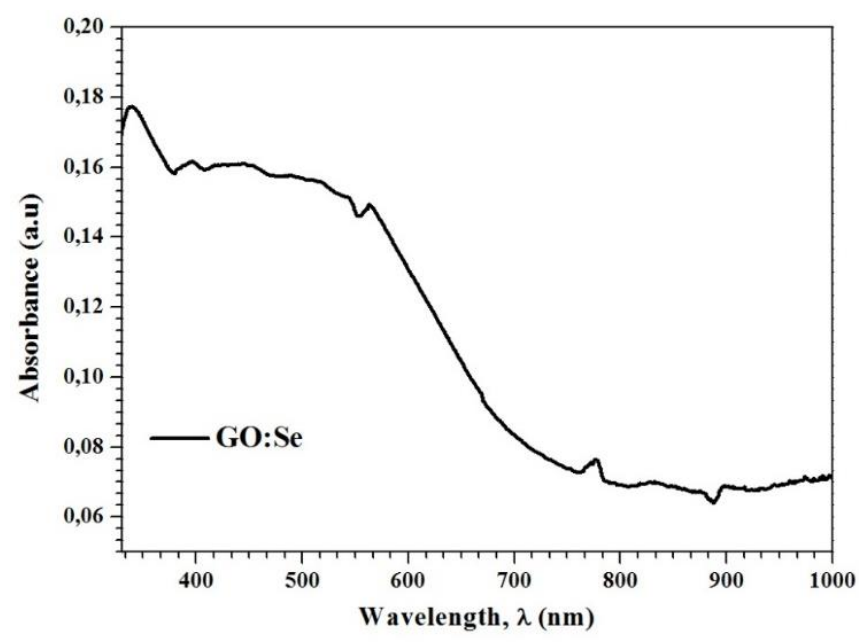

Figure 2: The optical absorbance of GO:Se thin film is deposited on a glass substrate versus the wavelength of incident photons.

The optical band gap energy (Eg) value of the thin film sample is calculated substituting the values of absorption coefficients, $\alpha$, corresponding to each wavelength into Equ. 1 given as following:

$$
a h v=A\left(h v-E_{g}\right)^{n}
$$

where A, h, Eg, hv, and $\mathrm{n}$ are $\alpha$ absorption coefficient values constant related to the effective masses of charge carriers, the Planck constant, the band gap energy, the energy of the photon, and the exponent that depends on the nature of the optical transition. By using Equ. 2 and for the direct transition $(n=1 / 2)$ [Çakıc1 et al., 2015], the graphic of the $(a h v)^{2}$ versus hv was plotted (Fig.3). As seen from Fig.3, after applying the extrapolation, the intercept on the hv-axis gives the value of the direct band gap of GO: Se thin film sample as approximately $1.70 \mathrm{eV}$ which is found firstly by this study for this material.

$$
(a h v)^{2}=A\left(h v-E_{g}\right)
$$

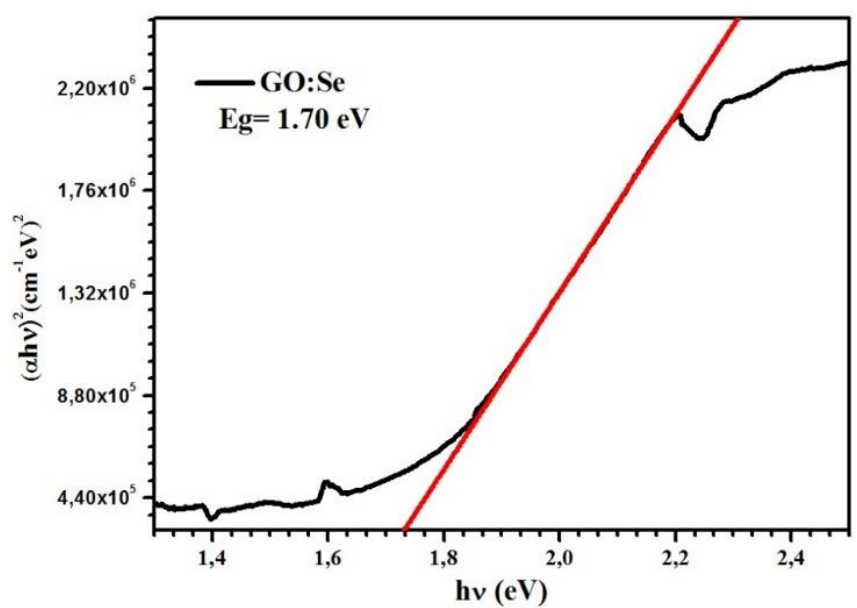

Figure 3: $(\mathrm{ahv})^{2}$ plot versus photon energy (hv) and the band gap energy $\left(\mathrm{E}_{\mathrm{g}}\right)$ determined by extrapolation for GO:Se thin film sample.

\subsection{Structural properties}

XRD peaks of the GO: Se/p-Si structure (red line) are shown in Fig. 4. The (h,k,l) diffraction planes of GO: Se thin film is displayed in Fig. 4. Herein, the strongest peak appearing at $2 \theta \sim 70^{\circ}$ and directed as (100) corresponds p-Si (100) with cubic crystallization. On the other hand, two peaks of the GO: Se structure, one of them is weak and the other is strong, emerge. These two weak and strong peaks appearing at about $23.11^{\circ}$ and $9.14^{\circ}$ belong to (002) directional plane of GO layers with different interlayer distances 
which are 0.38 and $0.97 \mathrm{~nm}$, respectively. This difference between these structures can be referred to as some structural defects and the existence of the oxygen-containing [Robinson et al., 2008; Wang et al., 2008].

As shown in Fig. 4, GO: Se thin film have two strong peaks, therefore it exhibits a polycrystalline thin film nature. Crystallite sizes of polycrystalline GO: Se thin film according to the different $2 \Theta$ angles were calculated by using Debye-Scherrer's formula,

$$
D=\frac{0,9 \lambda}{\beta \cos \theta}
$$

Herein, $\mathrm{D}$ is crystallite size, $\beta$ is the full width at half maximum (FWHM) and $\lambda$ is the wavelength of the X-ray ( $\lambda=1.5405 \AA)$. XRD parameters of the GO: Se thin film is given in Table 1.

Tablo 1. XRD structural parameters of GO:Se thin film

\begin{tabular}{lllllll}
\hline (hkl) & FWHM & FWHM (rad) & $\begin{array}{l}\text { Intensity } \\
\text { (a.u.) }\end{array}$ & $\mathbf{2 \theta}^{\mathbf{0}}$ (Observed) & d-values (nm) & $\begin{array}{l}\text { Crystal size (D) } \\
\text { nm }\end{array}$ \\
\hline$(002)$ & 3.58 & 0.062 & 4745.10 & 9.36 & 0,94 & 2,23 \\
$(002)$ & 0.165 & 0.003 & 559.12 & 23.11 & 0,38 & 49,15 \\
\hline
\end{tabular}

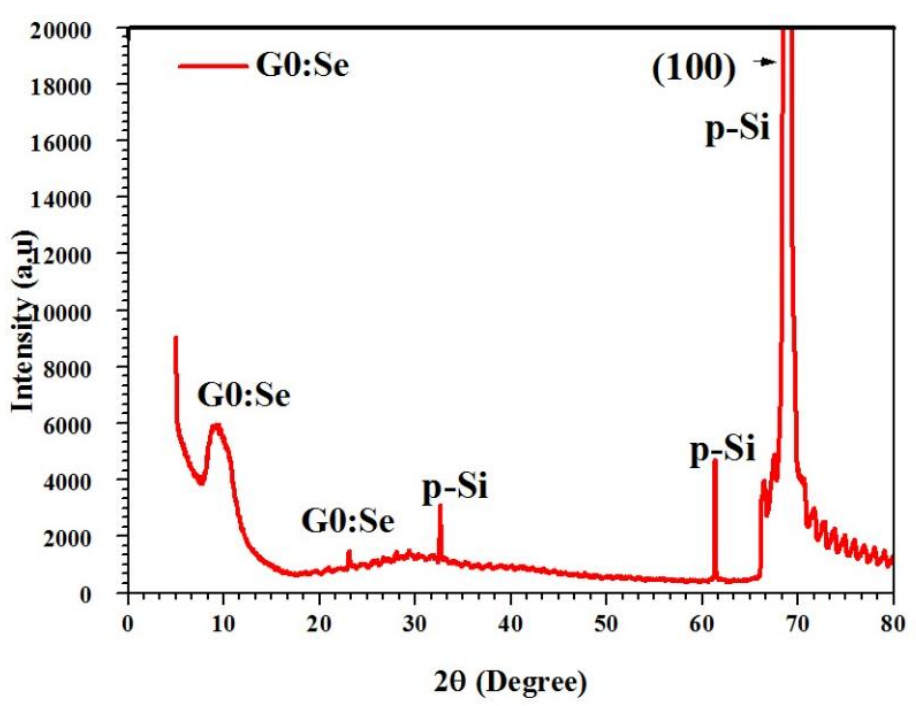

Figure 4: XRD peaks of the GO:Se /p-Si structure.

For the investigation of the structural properties such as morphology and composition of the GO:Se /p-Si structure, it was used the data procured from the FE-SEM and EDX analysis techniques.

Fig. 5 displays FE-SEM images of GO: Se thin film is deposited on the p-Si substrate and herein, it is seen that the formation of graphene oxide layers [Karteri and Güneş, 2016]. Also, sectional nanoscale GO: Se thin film FE-SEM image in the range of $200 \mathrm{~nm}$ displays the typical sheeted structure of the graphene oxide layer.

The EDX spectrum showing the component elements in the GO: Se/p-Si structure is given Fig. 6 and component elements percentages are given in the list, taking place in the composition of GO: Se/p-Si structure. According to this list, it is consisted of expected elements for GO: Se/p-Si structure, O, Se, C, and Si.

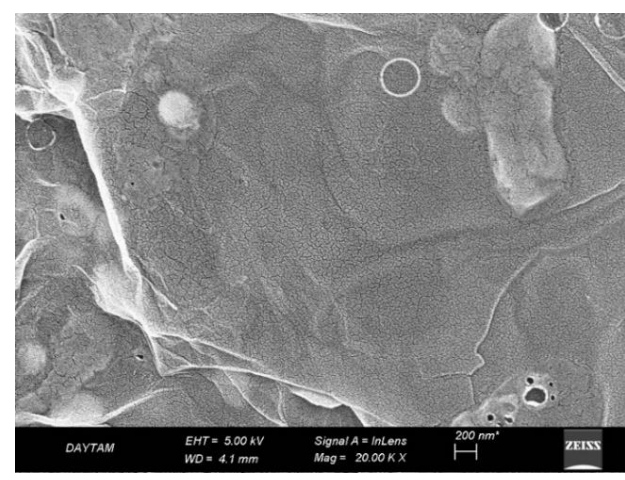

Figure 5: FE-SEM images of GO:Se /p-Si heterostructure with magnification scale (200nm). 


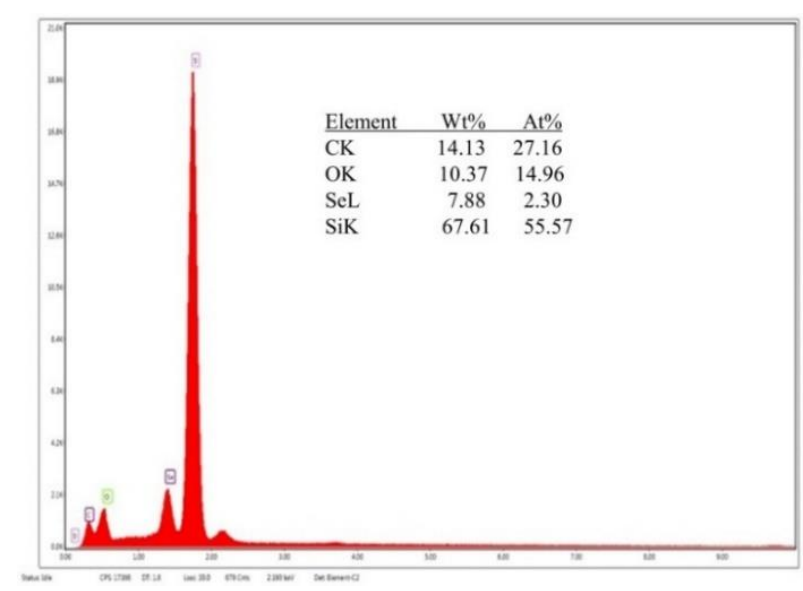

Figure.6: EDX spectrum image of the GO:Se/p-Si structure and the list of the elements detected.

\subsection{I-V Characteristics}

The current-voltage characteristic pilot of $\mathrm{Ag} / \mathrm{GO}: \mathrm{Se} / \mathrm{p}-\mathrm{Si} / \mathrm{Al}$ diode structure is shown in Fig.7. According to the Thermionic Emission theory ( $\mathrm{V} \geq 3 \mathrm{kT} / \mathrm{q}$ ) are calculated to find numerical values of some parameters of the diode structure, such as ideality factor, $\mathrm{n}$, barrier height, $\phi_{b}$, and saturation current $\mathrm{I}_{0}$. For the calculation numerical values of these parameters, the mathematical expression (Equation 4) of thermionic emission theory has been used given as following:

$$
I=\underbrace{A A^{*} T^{2} \exp \left(\frac{q \Phi_{B}}{k T}\right)}_{I_{0}}\left[\exp \left(\frac{q V}{n k T}\right)-1\right]
$$

Herein, $\mathrm{I}_{0}$ is the reverse-saturation current determined from the intercept of the straight line drawn from the linear region of the forward-bias $\ln (I)-V$ graph at $\mathrm{V}=0 . \mathrm{I}_{0}$ is given the following expression:

$$
I_{0}=A A^{*} T^{2} \exp \left(\frac{q \phi_{b}}{k T}\right)
$$

Herein, $\mathrm{A}, \mathrm{A}^{*}$, and $\mathrm{T}$ are the diode area $\left(=7.85 \times 10^{-3} \mathrm{~cm}^{2}\right)$, Richardson constant $\left(\mathrm{A}^{*}=32 \mathrm{Acm}^{-2} \mathrm{~K}^{-2}\right.$ for $\mathrm{p}$-type $\left.\mathrm{Si}\right)$ and the temperature of the media respectively.

Substituting the numerical values of these parameters into Eq. 5, saturation current value was obtained as $1.13 \times 10^{-10} \mathrm{~A}$ at room temperature. Moreover, ideality factor and barrier height values for $\mathrm{V} \geq 3 \mathrm{kT} / \mathrm{q}$ are derived from the Eq. 5 . They are given as follows:

$$
\begin{aligned}
& n=\frac{q}{k T} \exp \left(-\frac{d V}{d l n I}\right) \\
& \phi_{b}=\frac{k T}{q} \ln \left(-\frac{A A^{*} T^{2}}{I_{0}}\right)
\end{aligned}
$$

Hence, $n$ and $\phi_{b}$ values of the $\mathrm{Ag} / \mathrm{GO}$ : $\mathrm{Se} / \mathrm{p}-\mathrm{Si} / \mathrm{Al}$ diode structure was calculated as 2.16 and $0.86 \mathrm{eV}$, respectively. A rather higher ideality factor value can be attributed to non-uniform distribution of the carriers in the interface layer and barrier inhomogeneity [Çakıcı et al., 2015]. 


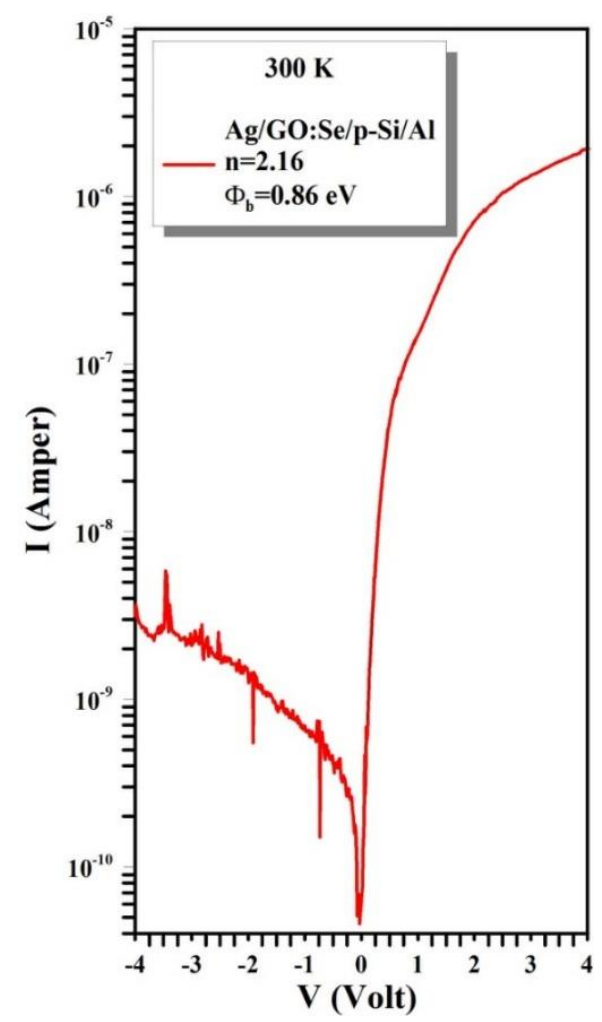

Figure.7. Current-Voltage (I-V) characteristics pilot of Ag/GO:Se/p-Si/Al.

\section{Conclusion}

In this report, GO: Se nanoparticles were synthesized via the bacterial green synthesis method and used them as an interfacial thin film in the production of $\mathrm{Ag} / \mathrm{GO}: \mathrm{Se} / \mathrm{p}-\mathrm{Si} / \mathrm{Al}$ diode structure, for the first time. GO: Se thin films were deposited glass and p-Si substrates. Optical and electronic, crystal structure, morphology, the composition of these thin films were characterized by absorption (UV.Vis.), XRD, FE-SEM with EDS methods. XRD peaks displayed to nano polycrystalline structure of GO: Se thin film with typical GO peaks position. FE-SEM image revealed that the GO: Se thin film has a nanosheets structure and EDS measurement depicted that the structures have a composition with the expected elements. All of these obtained results from measurements showed that GO: Se thin film was obtained successfully. Fabricated Ag/GO: Se/p-Si/Al diode structure some electrical parameters were tested by the current-voltage method at room temperature and dark conditions. Saturation current, ideality factor and barrier height of diode structure were determined as related to the thermionic emission theory of, $1.13 \times 10^{-10} \mathrm{~A}, 2.16$ and $0.86 \mathrm{eV}$, respectively. Consequently, all findings show that this device structure has relatively well and consistent diode characteristics. On the other hand, some further studies are planned to prove whether this structure can be used in photovoltaic cells or not.

\section{References}

Bakir M, Meyer JL, Hussainova I, Sutrisno A, Economy J, Jasiuk I, 2017. Periodic Functionalization of Graphene-Layered Alumina Nanofibers with Aromatic Thermosetting Copolyester via Epitaxial Step-Growth Polymerization. Macromolecular Chemistry and Physics, 218(24); 1700338.

Chen S, Zhu J, Wu X, Han Q, Wang X, 2010. Graphene oxide- MnO2 nanocomposites for supercapacitors. ACS Nano, 4(5); 28222830.

Çakıcı T, Güzeldir B, Sağlam M, 2015. Temperature-dependent of electrical characteristics of Au/n-GaAs/In Schottky diode with In2S3 interfacial layer obtained by using spray pyrolysis method. Journal of Alloys and Compounds, 646; 954-965.

Çakıcı T, Sağlam M, Güzeldir B, 2015. The comparison of electrical characteristics of Au/n-InP/In and Au/In2S3/n-InP/In junctions at room temperature. Materials Science and Engineering: B, 193; 61-69.

Elsoud MMA, Al-Hagar OE, Abdelkhalek ES, Sidney NM, 2018. Synthesis and investigations on tellurium my nanoparticles. Biotechnology Reports, 18; e00247.

Gurunathan S, Han JW, Eppakayala V, Kim JH, 2013. Biocompatibility of microbially reduced graphene oxide in primary mouse embryonic fibroblast cells. Colloids and surfaces B: Biointerfaces, 105; 58-66.

Husseiny MI, El-Aziz MA, Badr Y, Mahmoud MA, 2007. Biosynthesis of gold nanoparticles using Pseudomonas aeruginosa. Spectrochimica Acta Part A: Molecular and Biomolecular Spectroscopy, 67(3-4); 1003-1006.

Jilani SM, Gamot TD, Banerji P, Chakraborty S, 2013. Studies on resistive switching characteristics of aluminum/graphene oxide/semiconductor nonvolatile memory cells. Carbon, 64; 187-196.

Kang SH, Fang TH, Hong ZH, 2013. Electrical and mechanical properties of graphene oxide on flexible substrate. Journal of Physics and Chemistry of Solids, 74(12); 1783-1793. 
Karteri İ, Güneş M, 2016. Synthesis of reduced graphene oxide-phosphorus nanocomposites with a new approach for dye sensitized solar cells applications. Journal of Materials Science: Materials in Electronics, 27(11); 11502-11508.

Kaya A, Alialy S, Demirezen S, Balbaşı M, Yerişkin SA, Aytimur A, 2016. The investigation of dielectric properties and ac conductivity of $\mathrm{Au} / \mathrm{GO}$-doped $\mathrm{PrBaCoO}$ nanoceramic/n-Si capacitors using impedance spectroscopy method. Ceramics International, 42(2); 3322-3329.

Kocyigit A, Karteri İ, Orak I, Uruş S, Çaylar M, 2018. The structural and electrical characterization of Al/GO-SiO2/p-Si photodiode. Physica E: Low-dimensional Systems and Nanostructures, 103; 452-458.

Kumar CG, Mamidyala SK, 2011. Extracellular synthesis of silver nanoparticles using culture supernatant of Pseudomonas aeruginosa. Colloids and Surfaces B: Biointerfaces, 84(2); 462-466.

Li ZJ, Yang BC, Zhang SR, Zhao CM, 2012. Graphene oxide with improved electrical conductivity for supercapacitor electrodes. Applied Surface Science, 258(8); 3726-3731.

Liu CP, Hui YY, Chen ZH, Ren JG, Zhou Y, Tang L, Tang YB, Zapien JA, Lau, S. P. 2013. Solution-processable graphene oxide as an insulator layer for metal-insulator-semiconductor silicon solar cells. RSC advances, 3(39); 17918-17923.

Mekki A, Dere A, Mensah-Darkwa K, Al-Ghamdi A, Gupta RK, Harrabi K, Farooq WA, Tantawy F.El, Yakuphanoglu F, 2016. Graphene controlled organic photodetectors. Synthetic Metals, 217, 43-56.

Mekki A, Ocaya RO, Dere A, Al-Ghamdi AA, Harrabi K, Yakuphanoglu F, 2016. New photodiodes based graphene-organic semiconductor hybrid materials. Synthetic Metals, 213; 47-56.

Oremland RS, Herbel M J, Blum J S, Langley S, Beveridge T J, Ajayan PM, Sutto T, Ellis AV, Curran S, 2004. Structural and spectral features of selenium nanospheres produced by Se-respiring bacteria. Applied Environment Microbiology, 70(1); 52-60.

Ozdal M, Gurkok S, Ozdal OG, 2017. Optimization of rhamnolipid production by Pseudomonas aeruginosa OG1 using waste frying oil and chicken feather peptone. 3 Biotech, 7(2); 117.

Ozdal M, Ozdal OG, Algur O F, 2016. Isolation and characterization of $\alpha$-endosulfan degrading bacteria from the microflora of cockroaches. Polish journal of microbiology, 65(1); 63-68.

Özdal ÖG, Özdal M, Algur Ö F, Sezen A, 2016. Isolation and identification of $\alpha$-Endosulfan degrading bacteria from insect microflora. Turkish Journal of Agriculture-Food Science and Technology, 4(4); 248-254.

Ponarulselvam S, Panneerselvam C, Murugan K, Aarthi N, Kalimuthu K, Thangamani S, 2012. Synthesis of silver nanoparticles using leaves of Catharanthus roseus Linn. G. Don and their antiplasmodial activities. Asian Pacific journal of tropical biomedicine, 2(7); 574-580.

Prakash A, Sharma S, Ahmad N, Ghosh A, Sinha P, 2010. Bacteria mediated extracellular synthesis of metallic nanoparticles. Int Res J Biotechnol, 1(5); 071-079.

Raddadi N, Cherif A, Daffonchio D, Neifar M, Fava F, 2015. Biotechnological applications of extremophiles, extremozymes and extremolytes. Applied microbiology and biotechnology, 99(19); 7907-7913.

Raddadi N, Cherif A, Daffonchio D, Neifar M, Fava F, 2015. Biotechnological applications of extremophiles, extremozymes and extremolytes. Applied microbiology and biotechnology, 99(19); 7907-7913.

Robinson JT, Zalalutdinov M, Baldwin JW, Snow ES, Wei Z, Sheehan P, Houston BH, 2008. Wafer-scale reduced graphene oxide films for nanomechanical devices. Nano letters, 8(10); 3441-3445.

Wadhwani SA, Gorain M, Banerjee P, Shedbalkar UU, Singh R, Kundu GC, Chopade BA, 2017. Green synthesis of selenium nanoparticles using Acinetobacter sp. SW30: Optimization, characterization and its anticancer activity in breast cancer cells. International journal of nanomedicine, 12; 6841.

Wang X, Zhi L, Müllen K, 2008. Transparent, conductive graphene electrodes for dye-sensitized solar cells. Nano letters, 8(1); 323327.

Yoshida N, Miyata Y, Doi K, Goto Y, Nagao Y, Tero R, Hiraishi A, 2016. Graphene oxide-dependent growth and self-aggregation into a hydrogel complex of exoelectrogenic bacteria. Scientific reports, 6; 21867. 